\title{
ALS Diagnostic in the Electrodiagnostic Department of an Orthopedic Hospital during 2014-2015. Clinical and Electrophysiological Characteristic
}

\author{
Aymeé Hernández Hernández ${ }^{1,2 *}$ \\ ${ }^{1}$ Neurophysiology Department, Cuban Neuroscience Center, Cuba \\ ${ }^{2}$ Electrodiagnostic department, "Frank Pais" hospital, Cuba
}

Submission: January 06, 2016; Published: January 28, 2016

*Corresponding author: Aymeé Hernández Hernández, Clinical Neurophysiologist, Neurophysiology Department of Cuban Neuroscience Center, Electrodiagnostic department of "Frank Pais" hospital, Cuba, Tel: (53)7-2610659; Email: barbara@cneuro.edu.cu

\begin{abstract}
Introduction: Amyotrophic Lateral Sclerosis (ALS) is an uncommon illness, it is caused by motor neuron degeneration; upper, lower and bulbar muscles are affected. The diagnostic is based in Scorial criteria. In some cases it needs to be differentiating from orthopedic illness. ALS diagnosis in electrodiagnostic lab of "Frank Pais" orthopedic hospital has been 2-3 patients per year in the last 5 years.

Method: During January 2014-January 2015, nine patients were evaluated, four of them had ALS diagnosis and the other five were diagnosed like orthopedic illness. Sensory and by segments motor nerve conduction studies, electromyography, somato-sensory evoked potentials (SSEP) and Magnetic Resonance Image (MRI) were done to them.

Results: The age of patients was from 30-60 years old. Eight of them were male and one was female. Illness started in upper extremities in $55.5 \%$ of patients; it was in concordance with percent of muscle atrophy at physical exam. Clinical fasciculation were present in all patients, in $22.2 \%$ bulbar muscle were affected. Hyperreflexia was present in $44.4 \%$ and plantar reflex was abnormal in $100 \%$. Nerve conduction was abnormal in $77.7 \%$, SSEP were abnormal in $44.4 \%$ and EMG abnormalities were observed in $100 \%$ of patients. MRI was abnormal in $66.6 \%$, it showed not specific abnormalities.

Conclusions: ALS patients increased in electrodiagnostic lab of orthopedic "Frank Pais" hospital in relation to previous five years. Almost patients had initial orthopedic illness diagnosis. Electrophysiological and image studies confirmed ALS diagnosis in $100 \%$ of cases.

Keywords: ALS; EMG; Nerve Conduction Studies; Somato-Sensory Evoked Potentials; Orthopedic Illness

Abbreviations: ALS: Amyotrophic Lateral Sclerosis; MRI: Magnetic Resonance Image; SSEP: Somatosensory Evoked Potential; EMG: Electromyography
\end{abstract}

\section{Introduction}

Amyotrophic Lateral Sclerosis (ALS) is a progressive neurodegenerative disorder of unknown cause. The symptoms of the disease begin gradually over weeks and months, usually on one side of the body initially, and get progressively worse [1,2]. It is classified as G12.2 in International Statistical Classification of Diseases and Related Health Problems (ICD-10) of 2015. It is characterized by diffuse involvement of cortical, bulbar and spinal motor neurons. To diagnosis this illness is necessary demonstrate abnormalities of upper (hyperreflexia, hypertonia, clonus and Babinski's sign) and lower motor neuron (muscular atrophy, muscular weakness and fasciculation's) [1-5]. The criteria diagnosis for ALS was defined in the World Federation of Neurology Meeting at Escorial, in 1994 [6]. There are no specific tests to diagnose ALS, but neurophysiological studies are a basic tool for ALS diagnostic. Imaging studies, especially Magnetic Resonance Image (MRI) is very useful to differentiate ALS from others diseases, like multiple sclerosis, cervical spondylosis, cord tumor, syringomyelia, that could be similar to ALS [7-9].

In Europe and the United States, ALS affects about 2 people per 100000 habitants per year. In Cuba there isn't exactly statistic about incidence and mortality by ALS, but the highest 
institution that evaluate neurological disorder like Cuban National Neurological Institute reports, 2-4 cases at week, 8-16 monthly and 200 patients by year. At present there is not an effective treatment to ALS in stop the disease [1-2]. During 2014-2015 period we observed an increase of number of ALS cases that assisted to our Electrodiagnostic department. It was situated at orthopedic hospital. The majority of those cases went to Electrodiagnostic department with presumptive diagnosis of some orthopedic disease, and at the Electrodiagnostic department the ALS diagnosis was suspected by the results of Neurophysiological tests.

\section{Objective}

Characterize clinical and electrophysiological parameters of a group of ALS patients that went to Electrodiagnostic department of an orthopedic hospital.

\section{Method}

It is a prospective and descriptive study. Nine patients were evaluated, eight male and one female, the patients age was from 30 to 60 years old, mean age was 48.6 years old. Those patients went to Electrodiagnostic department of orthopedic "Frank Pais" hospital in 2014-2015 year; the presumptive diagnostic in all cases was orthopedic disease, due to their symptoms; but physical examination showed signs that had suspected ALS like differential diagnosis. Evolution time of disease was from one month to six months, mean 3.5 months.

Motor and sensory nerve conduction study of Median, Cubital, Deep Peroneal and Sural nerves, Somatosensory evoked potential (SSEP) of Posterior Tibial nerve were done to all of them. We also evaluated four extremities and bulbar muscles by needle Electromyography (EMG). Neuronica 5 equipment was used to do electrophysiological tests. MRI of cervical spine was done to differentiate any disease that could justify clinical signs, 0.3 tesla equipment was used to do MRI; T1 and T2 image with sagittal cut and myelography were obtained for each one of patient.

\section{Results}

Graphic 1 shows number of cases that have been diagnosticated with ALS in Electrodiagnostic department of Orthopedic "Frank Pais" hospital from 2009-2014; notice that the number of the cases increased in the last year respect previous years. Most of patients showed clinical onset in upper extremities, $66 \%$ of cases, nobody showed affectation of bulbar muscle at onset. Muscular atrophy was a frequent sign; it appeared at upper members in $77 \%$ of cases and at lower members in $66 \%$ of cases. Almost patients showed hyperreflexia of deep reflex, fundamentally in lower extremities (66\%), fasciculation was observed in $100 \%$ of cases at upper, lower and bulbar muscle. All of patients showed Babinski sign. Nobody showed sphincter abnormalities (Graphic 2).

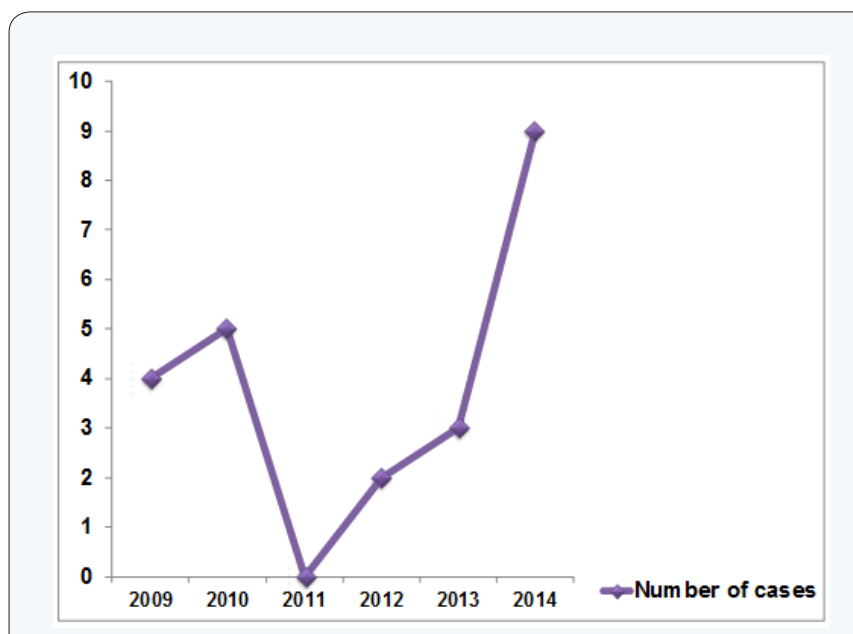

Graphic 1: Number of cases that have been diagnosticated with ALS in Electrodiagnostic department of Orthopedic "Frank País" hospital from 2009-2014.

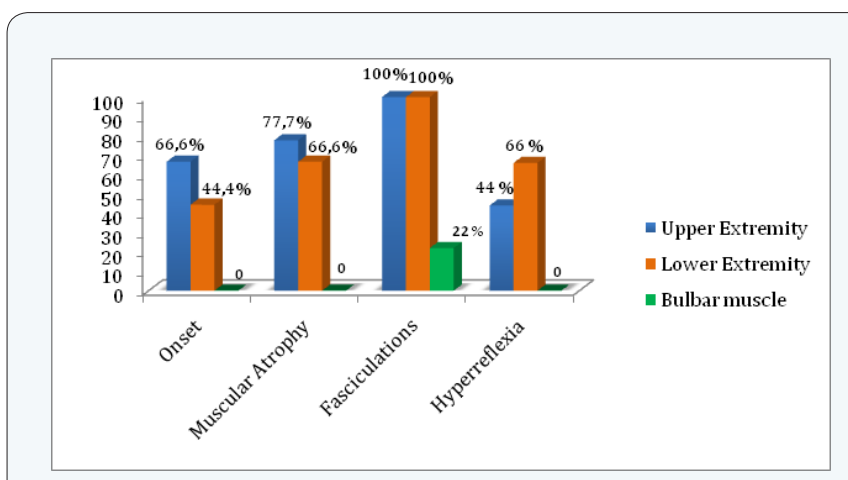

Graphic 2: Clinical signs of the ALS patients.

Neurophysiological studies showed some kind of abnormalities in almost patients, Electromyography confirmed neurogenic pattern in two or three anatomical regions in 100 $\%$ of cases (Figure 1), it shows maximum contraction isolate pattern, and this kind of abnormality is very frequent in neurogenic pattern. Nerve conduction study was abnormal in 66 $\%$ of cases and Somato- sensory evoked potential was abnormal in $33 \%$ of cases. MRI was abnormal in $44 \%$ of the patients. It showed little disc herniation, little osteophytes or narrow of cervical spaces, but those abnormalities don't justify the clinical symptoms of the patients (Graphic 3).

In motor nerve conduction studies Deep Peroneal nerve was the most affected, in $55.5 \%$ of cases, it is in relation of onset of clinical symptoms in lower members, (Figure 2). Sensory studies showed abnormalities predominantly in Median nerves, in $55 \%$ of cases; (Graphic 4). Figure 3, it shows amplitude diminishes of motor nerve response at Deep Peroneal nerve, its means axonal damage of this nerve.

Table 1 of the appendix shows a resume of clinical data and tests results of the nine ALS evaluated patients. 


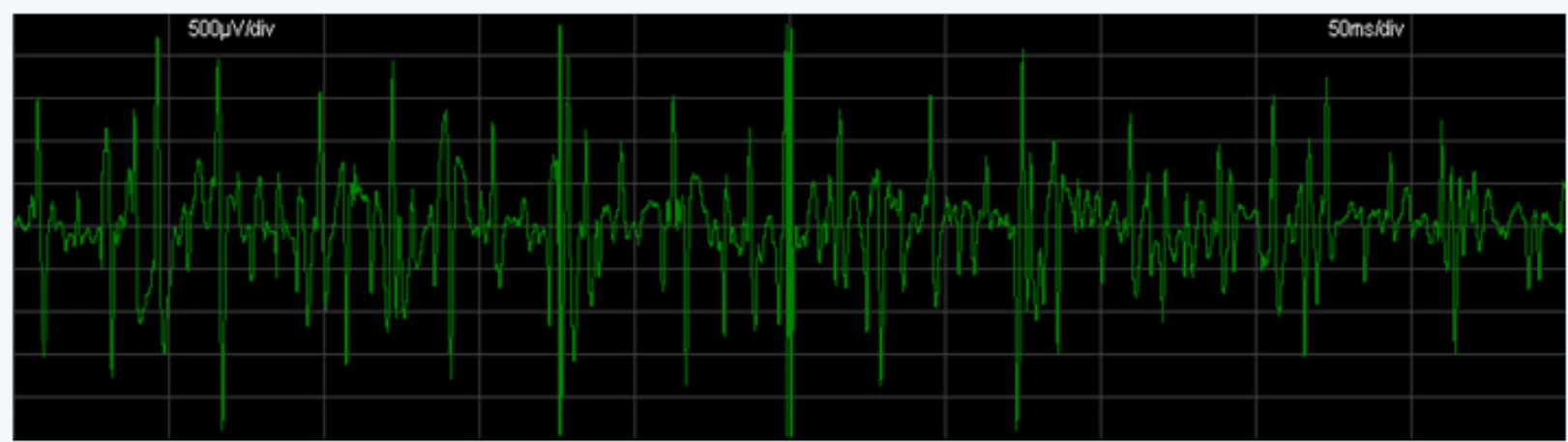

Figure 1: Electromiography of left Femoral Vastus muscle in an ALS patient. Note maximum contraction isolate pattern.
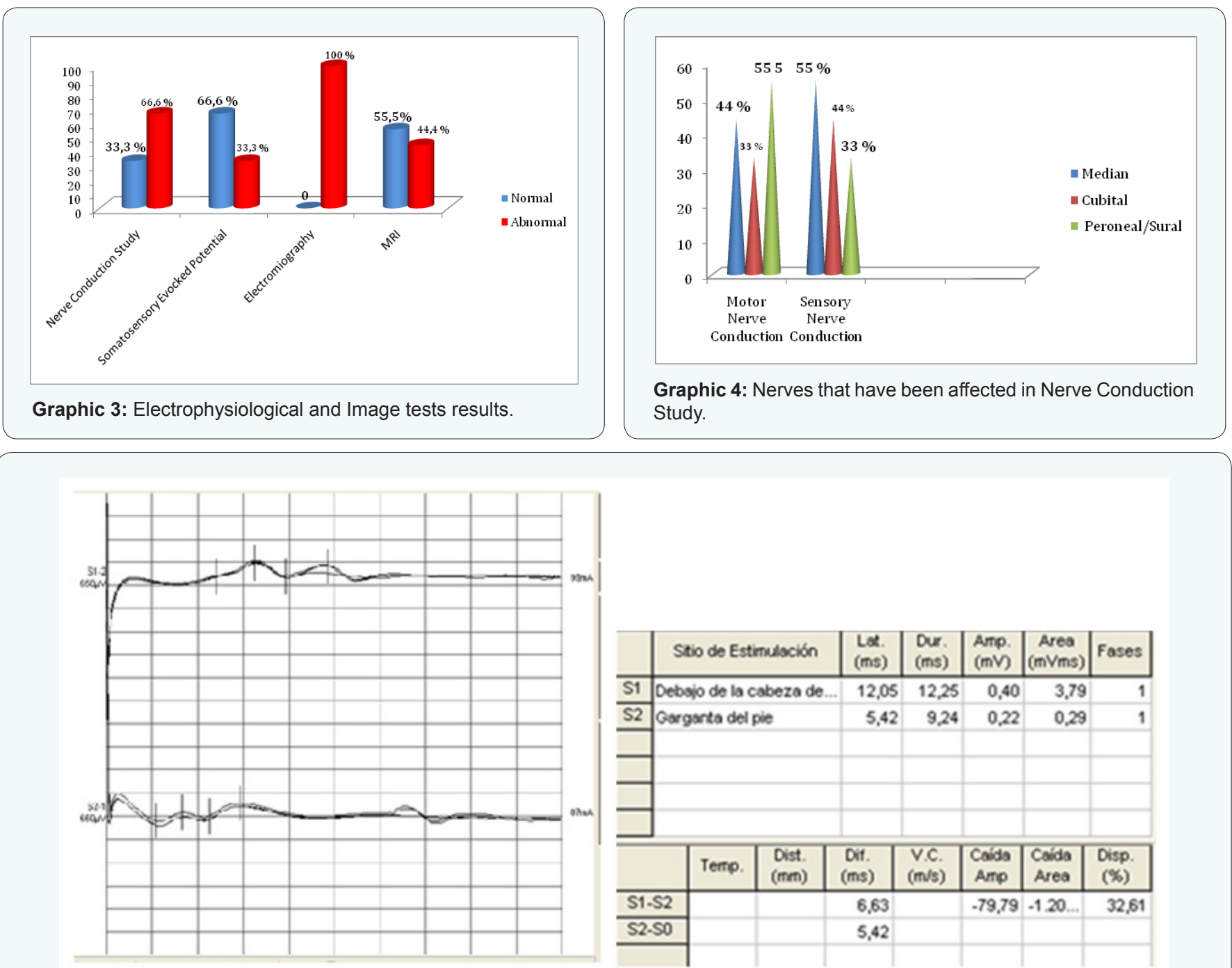

\begin{tabular}{|c|c|c|c|c|c|c|c|}
\hline & \multicolumn{2}{|c|}{ Stio de Estimulación } & \begin{tabular}{|l|} 
Lox. \\
(ms)
\end{tabular} & $\begin{array}{l}\text { Dur. } \\
\text { (ms) }\end{array}$ & $\begin{array}{l}\text { Amp. } \\
\text { (mV) }\end{array}$ & $\begin{array}{c}\text { Area } \\
\text { (mVms) }\end{array}$ & Fases \\
\hline S1 10 & \multicolumn{2}{|c|}{ Debajo de la cabeza de. } & 12,05 & 12,25 & 0,40 & 3,79 & 1 \\
\hline $\mathrm{s} 2$ & \multicolumn{2}{|c|}{ Gargarta del pie } & 5.42 & 9.24 & 0,22 & 0.29 & 1 \\
\hline \multicolumn{8}{|c|}{-1} \\
\hline \\
\hline \\
\hline \multicolumn{8}{|l|}{ 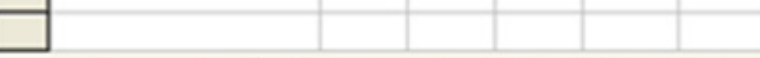 } \\
\hline & Temp. & $\begin{array}{l}\text { Dist. } \\
(\mathrm{mm})\end{array}$ & $\begin{array}{l}\text { Dif. } \\
\text { (ms) }\end{array}$ & $\begin{array}{l}\text { V.C. } \\
(\mathrm{m} / \mathrm{s})\end{array}$ & $\begin{array}{l}\text { Caida } \\
\text { Amp }\end{array}$ & $\begin{array}{l}\text { Caida } \\
\text { Area }\end{array}$ & $\begin{array}{l}\text { Disp. } \\
(\%)\end{array}$ \\
\hline S1.S & & & \multicolumn{2}{|l|}{6,63} & $-79,79$ & $-1.20 \ldots$ & 32,61 \\
\hline S2-So & so & & 5,42 & & & & \\
\hline
\end{tabular}

Figure 2: Motor nerve conduction of right Deep Peroneal nerve in an ALS patient Note markedly amplitude diminishes.

\section{Discussion}

\section{Age of onset}

Mean age of onset of our ALS patients is agree with other author's reports, we have only one case too young. He is 30 years old and he had not previous history of familial ALS [1-3].

Sex

In our group of patients predominated male patients [8]. It is agree with other reports. ALS predominates in male patients in a $2: 1$ proportion $[5,7,8]$. 


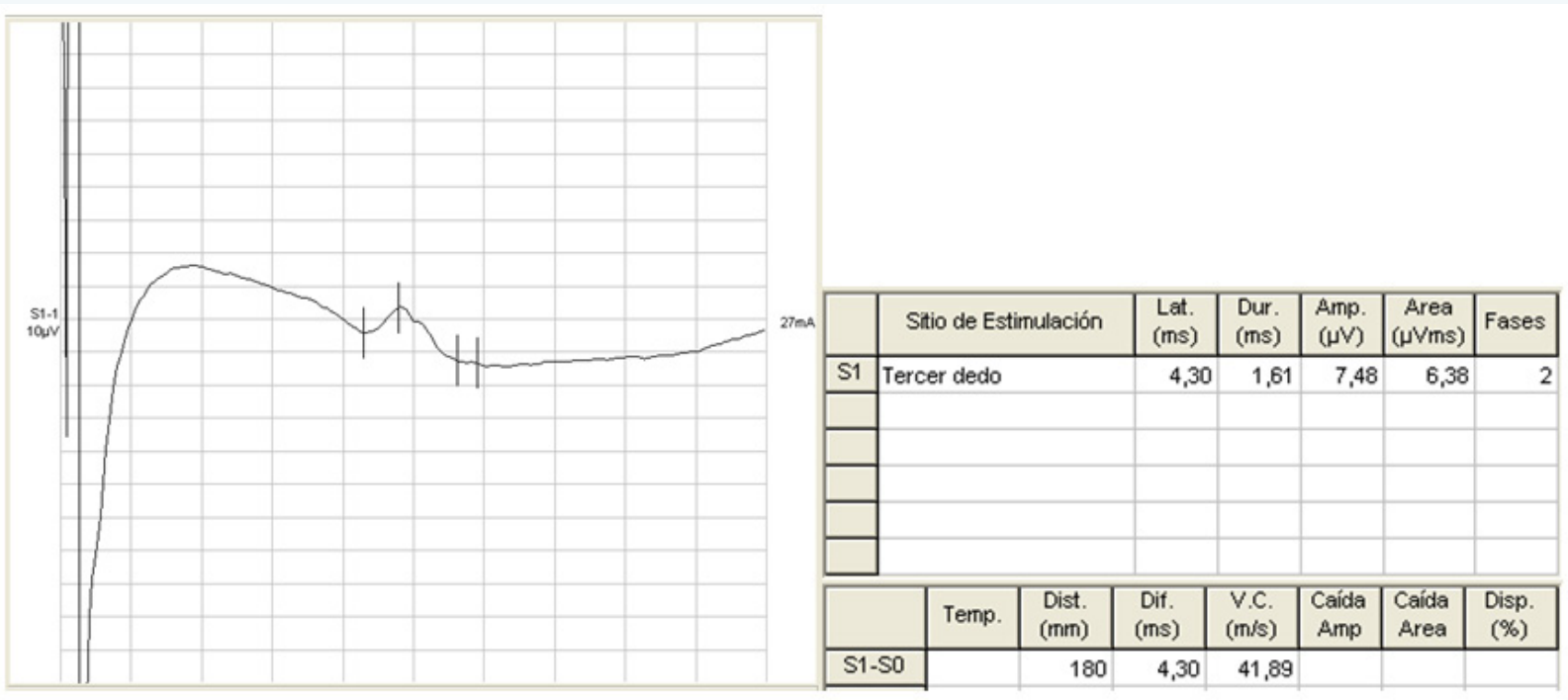

Figure 3: Sensory nerve conduction study of right Median nerve in ALS patient. Note markedly latency enlargement and slowing of nerve conduction velocity.

Table 1: Clinical dates and tests results of ALS patients

\begin{tabular}{|c|c|c|c|c|c|c|c|c|c|c|}
\hline Case & Age & Onset & $\begin{array}{c}\text { Evolution } \\
\text { Time }\end{array}$ & Physical exam & $\begin{array}{c}\text { Bulbar } \\
\text { symptoms }\end{array}$ & $\begin{array}{l}\text { Motor Nerve } \\
\text { Conduction }\end{array}$ & $\begin{array}{c}\text { Sensory } \\
\text { Nerve } \\
\text { Conduction }\end{array}$ & SSEP & EMG & MRI \\
\hline 1 & 30 & $\begin{array}{l}\text { Left upper } \\
\text { member }\end{array}$ & 2 months & $\begin{array}{l}\text { Muscular Tone } \\
\text { was normal. } \\
\text { Muscular force } \\
\text { was diminish } \\
\text { at left upper } \\
\text { member }\end{array}$ & No & $\begin{array}{c}\text { - Myelinic } \\
\text { damage of } \\
\text { Median, } \\
\text { Cubital } \\
\text { nerves. } \\
\text { - Axonal } \\
\text { damage of } \\
\text { Median and } \\
\text { Cubital nerves }\end{array}$ & $\begin{array}{l}\text { - Moderate } \\
\text { myelinic } \\
\text { damage of } \\
\text { Median, } \\
\text { Cubital and } \\
\text { Sural nerves }\end{array}$ & Abnormal & $\begin{array}{l}\text { Neurogenic } \\
\text { pattern } \\
\text { in two } \\
\text { anatomical } \\
\text { regions }\end{array}$ & Normal \\
\hline 2 & 59 & $\begin{array}{l}\text { Both lower } \\
\text { members } \\
\text { weakness } \\
\text { and lumbar } \\
\text { pain }\end{array}$ & 4 months & $\begin{array}{c}\text { Muscular } \\
\text { Tone was } \\
\text { diminishing at } \\
\text { lower members. } \\
\text { Muscular force } \\
\text { was diminish } \\
\text { at both lower } \\
\text { member }\end{array}$ & No & $\begin{array}{c}\text { - Axonal } \\
\text { damage of } \\
\text { both Peroneal } \\
\text { and left } \\
\text { Cubital nerves }\end{array}$ & $\begin{array}{l}\text { - Myelinic } \\
\text { damage } \\
\text { of Median } \\
\text { and Cubital } \\
\text { nerves }\end{array}$ & Abnormal & $\begin{array}{l}\text { Neurogenic } \\
\text { pattern } \\
\text { in two } \\
\text { anatomical } \\
\text { regions }\end{array}$ & Normal \\
\hline 3 & 55 & $\begin{array}{l}\text { Right upper } \\
\text { member } \\
\text { weakness } \\
\text { and cervical } \\
\text { pain }\end{array}$ & 4 months & $\begin{array}{l}\text { Muscular Tone } \\
\text { was normal. } \\
\text { Muscular force } \\
\text { was diminish } \\
\text { at right upper } \\
\text { member }\end{array}$ & No & $\begin{array}{c}\text { - Axono- } \\
\text { myelinic } \\
\text { damage of } \\
\text { both peroneal } \\
\text { nerves. } \\
\text { Myelinic } \\
\text { damage of } \\
\text { right Median } \\
\text { and Cubital } \\
\text { nerves. }\end{array}$ & $\begin{array}{l}\text { - Myelinic } \\
\text { damage } \\
\text { of Median } \\
\text { and Cubital } \\
\text { nerves }\end{array}$ & Normal & $\begin{array}{l}\text { Neurogenic } \\
\text { pattern } \\
\text { in two } \\
\text { anatomical } \\
\text { regions }\end{array}$ & Abnormal \\
\hline 4 & 44 & $\begin{array}{l}\text { Both lower } \\
\text { members } \\
\text { and lumbar } \\
\text { pain }\end{array}$ & 2 months & $\begin{array}{l}\text { Muscular Tone } \\
\text { was normal. } \\
\text { Muscular force } \\
\text { was diminish } \\
\text { at both lower } \\
\text { members }\end{array}$ & No & Normal & Normal & Normal & $\begin{array}{l}\text { Neurogenic } \\
\text { pattern } \\
\text { in three } \\
\text { anatomical } \\
\text { regions }\end{array}$ & Normal \\
\hline
\end{tabular}




\begin{tabular}{|c|c|c|c|c|c|c|c|c|c|c|}
\hline Case & Age & Onset & $\begin{array}{l}\text { Evolution } \\
\text { Time }\end{array}$ & Physical exam & $\begin{array}{c}\text { Bulbar } \\
\text { symptoms }\end{array}$ & $\begin{array}{l}\text { Motor Nerve } \\
\text { Conduction }\end{array}$ & $\begin{array}{l}\text { Sensory } \\
\text { Nerve } \\
\text { Conduction }\end{array}$ & SSEP & EMG & MRI \\
\hline 5 & 52 & $\begin{array}{l}\text { Left lower } \\
\text { member } \\
\text { weakness } \\
\text { and pain }\end{array}$ & 3 months & $\begin{array}{l}\text { Muscular Tone } \\
\text { was diminished } \\
\text { at both lower } \\
\text { members. } \\
\text { Muscular force } \\
\text { was diminish } \\
\text { at both lower } \\
\text { member }\end{array}$ & No & $\begin{array}{c}\text { - Myelinic } \\
\text { damage of } \\
\text { both Median } \\
\text { nerves. } \\
\text { Axonal } \\
\text { damage of } \\
\text { both Peroneal } \\
\text { nerves }\end{array}$ & $\begin{array}{l}\text { - Myelinic } \\
\text { damage } \\
\text { of right } \\
\text { Median } \\
\text { nerve }\end{array}$ & Normal & $\begin{array}{l}\text { Neurogenic } \\
\text { pattern } \\
\text { in three } \\
\text { anatomical } \\
\text { regions }\end{array}$ & Abnormal \\
\hline 6 & 46 & $\begin{array}{l}\text { Right upper } \\
\text { member } \\
\text { weakness } \\
\text { and cervical } \\
\text { pain }\end{array}$ & 4 months & $\begin{array}{l}\text { Muscular Tone } \\
\text { was diminished } \\
\text { at right upper } \\
\text { and lower } \\
\text { members. } \\
\text { Muscular } \\
\text { force was very } \\
\text { diminish at right } \\
\text { upper member }\end{array}$ & Yes & $\begin{array}{l}\text { - Axono- } \\
\text { myelinic } \\
\text { damage of } \\
\text { both Peroneal } \\
\text { and right } \\
\text { Median } \\
\text { nerves }\end{array}$ & $\begin{array}{c}\text { - Myelinic } \\
\text { damage of } \\
\text { both Sural } \\
\text { nerves }\end{array}$ & Normal & $\begin{array}{l}\text { Neurogenic } \\
\text { pattern } \\
\text { in three } \\
\text { anatomical } \\
\text { regions }\end{array}$ & Abnormal \\
\hline 7 & 46 & $\begin{array}{l}\text { Left lower } \\
\text { member } \\
\text { atrophy and } \\
\text { lumbar pain }\end{array}$ & 4 months & $\begin{array}{c}\text { Muscular Tone } \\
\text { was diminished } \\
\text { at both lower } \\
\text { members. } \\
\text { Muscular force } \\
\text { was diminish at } \\
\text { both members }\end{array}$ & No & Normal & Normal & Normal & $\begin{array}{l}\text { Neurogenic } \\
\text { pattern } \\
\text { in two } \\
\text { anatomical } \\
\text { regions }\end{array}$ & Normal \\
\hline 8 & 42 & $\begin{array}{l}\text { Right upper } \\
\text { member } \\
\text { atrophy and } \\
\text { cervical pain }\end{array}$ & $\begin{array}{c}1 \frac{1 / 2}{2} \\
\text { months }\end{array}$ & $\begin{array}{c}\text { Muscular Tone } \\
\text { was diminished } \\
\text { at both upper } \\
\text { members. } \\
\text { Muscular } \\
\text { force was very } \\
\text { diminish at both } \\
\text { upper members }\end{array}$ & No & Normal & Normal & Abnormal & $\begin{array}{l}\text { Neurogenic } \\
\text { pattern } \\
\text { in three } \\
\text { anatomical } \\
\text { regions }\end{array}$ & Normal \\
\hline 9 & 64 & $\begin{array}{l}\text { Left upper } \\
\text { member } \\
\text { weakness } \\
\text { and cervical } \\
\text { pain }\end{array}$ & 2 months & $\begin{array}{l}\text { Muscular Tone } \\
\text { was normal. } \\
\text { Muscular force } \\
\text { was diminish at } \\
4 \text { extremities }\end{array}$ & Yes & $\begin{array}{l}\text { - Axono- } \\
\text { myelinic } \\
\text { damage of } \\
\text { Median, } \\
\text { Cubital and } \\
\text { Peroneal } \\
\text { nerves }\end{array}$ & $\begin{array}{c}\text { - Axono- } \\
\text { myelinic } \\
\text { damage of } \\
\text { Median, } \\
\text { Cubital and } \\
\text { Sural nerves }\end{array}$ & Normal & $\begin{array}{l}\text { Neurogenic } \\
\text { pattern } \\
\text { in three } \\
\text { anatomical } \\
\text { regions }\end{array}$ & Normal \\
\hline
\end{tabular}

\section{Evolution time}

The mean evolution time of our cases was short (3.5 months), we observed those patients at the onset of disease. Authors report an evolution time about 3-5 years [1-3,5,7,8]. ALS is a severely life-shortening condition for most people. Life expectancy for about half of those with the condition is three years from the start of symptoms. However, some people may live for up to 10 years, and in rarer circumstances even longer [1-2].

\section{Incidence}

In Cuba rates of ALS are unknown. Cuban National Neurologic and Neurosurgery Institute is ALS reference center and it reports about 200 new ALS cases by year. This center has not reported an increase of ALS cases in 2014. We have not explanation to the increase of ALS cases during 2014 -2015 period at Electrodiagnostic department of orthopedic Frank Pais hospital. In Europe, the disease affects about 2.2 people per 100,000 per year. In the United States, more than 5,600 are diagnosed every year, and up to 30,000 Americans are currently affected. ALS is responsible for two deaths per 100,000 people per year. People of all races and ethnic backgrounds are affected. ALS cases are estimated at 1.2- 4.0 per 100,000 individuals in Caucasian populations with a lower rate in other ethnic populations. Filipinos are second to Caucasians in terms of ALS prevalence with 1.1-2.8 per 100,000 individuals [3].

\section{Clinic signs}

Authors have reported that ALS is an asymmetrical disease and at the onset arms or legs are most affected. Our group of patients had an asymmetrical onset, and arms were most 
affected (in $66 \%$ of cases). It is agree with author's reports $[1,2,4]$. Muscular atrophy was a constant sign, it appeared at upper members (in $77 \%$ of cases) and at lower members (in $66 \%$ ). It's agree with others reports. Muscular atrophy is one of the most common sign reported in ALS $[5,7,8]$. Muscle bulbar weakness was observed only in two patients. It isn't a frequent form of ALS onset; except in bulbar forms. Fasciculations were constant sign in all of cases, it affected upper, lower and bulbar muscles, fasciculation's were bothering and in some occasions they caused anguish to the patients $[1-5,7,8]$. Fasciculations are a common symptom of ALS. These persistent muscle twitches are generally not painful, but can be annoying or interfere with sleep. They are the result of the ongoing disruption of signals from the nerves to the muscles that occurs in ALS [8].

Most of authors are agree with this sign must be present to do ALS diagnosis. By the way, fasciculation's could appear in other diseases like: radiculopathies, plexopathies, neuropathies and in some health persons with anxiety or coffee or tea habits. In those last cases, fasciculation appear in localized areas, while in ALS fasciculation's are generalized and they appear more frequent in weak muscle. Hyperreflexia and Babinski sign are explained by first motoneuron abnormality. They appearance of these signs is in depend of stage of disease. For this reason ALS must be differentiated of Cervical Spondylotic Myelopathy, Cervical cord tumor, Syringomyelia, and Multiple Sclerosis. Magnetic Resonance Image let see these differences [1-5,7,8].

\section{Electrophysiological Tests}

The $33 \%$ of our cases showed normal nerve conduction studies without relation with evolution time of the disease. According to Gutiérrez Rivas nerve conduction studies could be normal in ALS if dying back degeneration has not occurred yet [9]. Motor nerve conduction study was abnormal in $66 \%$ of the cases. It showed axonal or axono-myelinic nerve damage. It is explained by dying back axonal degeneration, which appears after neuronal body degeneration. It is a very important point because this nerve conduction result could be confuse with axonal or axono-myelinic neuropathy, in those of them the nerve damage is distal; while in ALS nerve damage is proximal [9-20]. Deep peroneal nerve was the most affected motor nerve (in 55\% of the cases) although symptoms onset were reported at upper members. It means that motor fibers of lower members are most affected [9]. Sensory nerve conduction studies were abnormal in $66 \%$ of cases. The nerve damage was with predominance myelinic (5 cases), case number 9 showed absence of response in all sensory nerves, it is in relation with myelinic severe and/ or axonal damage of this fibers. Median nerve was the most affected sensory nerve; it is affected too for other pathologies like entrapments or neuropathies.

Some years ago some authors insured that sensory nerve conduction studies must be normal to ALS diagnosis. This planning has been relaxed because post-mortem studies in ALS have showed that there is degeneration of sensory nerves too, the most affected neurons are in dorsal root ganglia and in posterior horn. This degeneration is most slow and less intense that in motor neurons. This sensory abnormality doesn't express clinically, but it could be detect by electrophysiological tests. Sensory function in patients with amyotrophic lateral sclerosis (ALS) is thought to be normal; however, there is convincing morphologic evidence that sensory systems are affected in addition to motor systems. Shefner and collaborator in 1991 reported nine of 18 patients had abnormally reduced minimum conduction velocity, even when peak-to-peak amplitude and maximum conduction velocity (calculated from the latency to the initial positive peak) were normal. Only 3 of 18 patients showed abnormalities in peak-to-peak amplitude [21-23].

Pugdahl et al. in 2007 reported that of 41 sensory nerves examined in the ALS patient group, 32 (78\%) nerves had abnormal sensory nerve conduction parameters 10 had decreased sensory nerve conduction velocity, 14 had decreased sensory response amplitude and 2 nerves did not elicit any response. Morphological findings of sensory nerve biopsies from patients with ALS have shown axonal degeneration, segmental demyelination and a reduced number of large neurons of the L5 dorsal root ganglion [21]. Somato-sensory evoked potentials were abnormal in $33 \%$ of cases; the principal abnormality was enlargement of P40 wave latency (cortical response) and somato-sensory central conduction time. It means abnormality in conduction of gross myelinic fibers of dorsal lemniscal system between terminal cone of spinal cord and somato-sensory cortex. It was bilaterally and slight. It is in relation with sensory fibers degeneration because MRI study was normal in those patients; compressive lesions of spinal cord were eliminated $[23,24]$.

Iglesias et al. [22] published that according sensory nerve biopsy and multiparametric spinal imaging of the dorsal column have revealed subclinical anatomical damage in patients, including those at an early disease stage after diagnosis. From a pathophysiological perspective, the role of sensory involvement in the degenerative process in ALS is still unknown. Some authors like Dustman and Palma have suggested that abnormal SEPs in ALS are not due to sensory defects but to abnormal cortico-cortical interactions [23-29]. Peripheral and central degeneration of sensory pathways have also been reported in presymptomatic ALS mice, suggesting that the sensory defect occurs at a very early stage of the degenerative process [25-27].

Abnormal SEPs were reported, on average, in about $1 / 3$ patients without clinical sensory deficits and is more common when stimulating lower limb peripheral nerves than those of upper limbs. A recent cerebral MRI study has shown atrophy in the thalamus suggesting that the thalamocortical relay for sensory information may be altered in ALS [29]. Electromiography was abnormal in all case. It showed a 
neurogenic pattern in two or three anatomical regions. It is a most sensitive electrophysiological test in ALS diagnosis and let to sit the stage of disease and to prognosis the evolution [16-18].

\section{MRI test}

It was abnormal in $44 \%$ of cases (4 patients). It showed: small disk prolapse, light narrow of intervertebral spaces and spondylotic changes of cervical spine. Any case showed compression, tumor, syringomielic cavity, spondylotic myelopathy or another abnormality that could justify the patient's symptoms [30-32].

\section{Differential diagnosis}

Seven of nine patients that we evaluated consulted the doctor because orthopedic symptoms like cervical and lumbar pain; it was accompanied by weakness and/or muscle atrophy of one member. Physical examination, electrophysiological and images techniques reject orthopedic diseases like cause of patient's symptoms. Cervical spondylotic myelopathy is the most important orthopedic disease to be considerate to ALS differential diagnosis. In some occasions electrophysiological test is very similar in both diseases, with exception that Spondylotic myelopathy respect bulbar muscle [30-32].

Some authors like Yamada et al. in 2003 have reported that in occasions coexist both diseases (Spondylotic Myelopathy and ALS), in these occasions ALS is frequently complicated by cervical Spondylotic myelopathy. When the presence of ALS is missed, cervical spinal surgery is performed followed by progressive worsening of the motor symptoms despite successful treatment of cervical spondylosis [31]. In conclusion orthopedic disease can coexist with ALS and it could be the reason of consult of the patients. In our group of patients the onset of symptoms was predominantly in upper members, electromyography study confirmed ALS in all of cases and motor and sensory nerve conduction studies were affected in great measure. MRI studies always demonstrate that spine abnormalities don't justify all clinical symptoms of the patients.

\section{References}

1. Kiernan MC, Vucic S, Cheah BC, Turner MR, Eisen A, et al. (2011) Amyotrophic lateral sclerosis. Lancet 377 (9769): 942-955.

2. McDermott CJ, Shaw PJ (2008) Diagnosis and management of motor neuron disease. BMJ 336 (7645): 658-662.

3. Youngson DB, Jacoby RM (2004) Encyclopedia of family health $\left(3^{\text {rd }}\right.$ edn). Tarrytown, NY: Marshall Cavendish, pp. 1256.

4. Dugdale DC, Hoch DB, Zieve D (2010) Amyotrophic lateral sclerosis. A.D.A.M. Medical Encyclopedia.

5. Rooper AH, Brown RH, Adams and Victor's (2005) Principles of neurology. New York: McGraw-Hill, pp. 120-158.

6. Brooks BR (1994) El Escorial World Federation of Neurology Criteria for the diagnosis of amyotrophic lateral sclerosis. J Neurol Sci 124(Suppl1): 96-107.
7. García Gálvez P, Cambón S, Higes P, Sánchez Migallón MJ, Yustaizquierdo A (2011) Enfermedad de la motoneurona. Medicine 10: 5200-5208.

8. Montero J, Fernández JM (1999) Diagnóstico electrofisiológico. En: Mora JS (Ed.), Esclerosis lateral amiotrófica. Una enfermedad tratable Barcelona: ProusScience, S.A, pp. 157- 175.

9. Gutiérrez Rivas E, Jiménez MD, Pardo J, Romer J (2000) Manual de Electromiografía Clínica. Barcelona: ProusScience, S.A, pp. 177-186.

10. Behnia M, Kelly JJ (1991) Role of electromyography in amyotrophic lateral sclerosis. Muscle Nerve 14(12): 1236-1241.

11. Santos Anzorandia C (2003) El Abecé de la Electroneuromiografía clínica. La Habana: Ciencia Médicas 2000: 183-187.

12. Espadaler Gamissans JM (1996) Exploración electrofisiógica en las enfermedades de la motoneurona. Neurologia II(Suppl 5): 20-28.

13. Dina Avarvarei L, Patrignan-Ochoa JH, Castilla-Garrido JM, Jiménez-Castellano Ballesteros R, Ugarte Monasterio J (2005) Electromiograma de fibra única en 18 pacientes con esclerosis lateral amiotrófica. Rev Neurol 40: 141-144.

14. Cornblath DR, Kuncl RW, Mellitis ED, Quaskey BSSA, Lora Clawson BSN, et al. (1992) Nerve conduction studies in amyotrophic lateral sclerosis. Muscle Nerve 15(10): 1111-1115.

15. Pavlovic S, Stenic Z, Kectkarevic D, Rakocevic-Stojanovic V, Lavrnic D, et al. (2003) Sensory abnormalities in patients with amyotrophic lateral sclerosis. Muscle and Nerve 12(Suppl): 145.

16. Roger Álvarez Fiallo C, Esther Medina Herrera E (2004) La neurofisiología en el estudio de las enfermedades neuromusculares, desarrollo y limitaciones actuales. Rev Cub Med Mil 33(3): 15-18.

17. Boekestein WA, Kleine BU, Hageman G, Schelhaas HJ, Zwarts MJ (2010) Sensitivity and specificity of the "Awaji" electrodiagnostic criteria for amyotrophic lateral sclerosis: Retrospective comparison of the Awaji and revised El Escorial criteria for ALS. Amyotrophic Lateral Scler 11(6): 497-501.

18. Daube JR (2000) Electrodiagnostic studies in amyotrophic lateral sclerosis and other motor neuron disorders. Muscle nerve 23(10): 1488-1502.

19. Roger Álvarez Fiallo C, Carlos Santos Anzorandia C, Esther Medina Herrera C (2007) Diagnóstico electromiográfico de las enfermedades neuromusculares. Rev Cub Med Mil 36(1): 1-5.

20. Shefner JM, Tyler HR, Krarup C (1991) Abnormalities in the sensory action potential in patients with amyotrophic lateral sclerosis. Muscle Nerve 14(12): 1242-1246.

21. Pugdahl K, Fuglsang-Frederiksen A, De Carvalho M, Johnsen B, Fawcett PR, et al. (2007) Generalized sensory system abnormalities in amyotrophic lateral sclerosis: a European multicentre study. J Neurol Neurosurg Psychiatry 78(7): 746-749.

22. Iglesias C, Sangari S, El Mendili MM, Benali H, Marchand Pauvert V, et al. (2015) Electrophysiological and spinal imaging evidences for sensory dysfunction in amyotrophic lateral sclerosis. BMJ Open 5(2): e007659.

23. Dustman RE, Snyder EW, Callner DA, Beck EC (1979) The evoked response as a measure of cerebral dysfunction. In: Begleiter H (Ed.), Evoked brain potentials and behavior. New York: Plenum Press 2: 321-363.

24. Palma V, Guadagnino M, Brescia Morra V, Nolfe G (1993) Multimodality evoked potentials in sporadic amyotrophic lateral sclerosis: a statistical approach. Electromyogr Clin Neurophysiol 33(3): 167-171. 
25. Guo YS, Wu DX, Wu HR, Wu SY, Yang C, et al. (2009) Sensory involvement in the SOD1-G93A mouse model of amyotrophic lateral sclerosis. Exp Mol Med 41(3): 140-150.

26. King AE, Blizzard CA, Southam KA, Vickers JC, Dickson TC (2012) Degeneration of axons in spinal white matter in G93A mSOD1 mouse characterized by NFL and alpha-internexin immunoreactivity. Brain Res 1465: 90-100.

27. Sábado J, Casanovas A, Tarabal O, Hereu M, Piedrafita L, et al. (2014) Accumulation of misfolded SOD1 in dorsal root ganglion degenerating proprioceptive sensory neurons of transgenic mice with amyotrophic lateral sclerosis. Biomed Res Int 2014: 852163.

28. Ogata K, Tobimatsu S, Furuya H, Kira J (2001) Sporadic amyotrophic lateral sclerosis showing abnormal somatosensory evoked potentials: a report of three cases. Fukuoka Igaku Zasshi 92 (6): 242-250.
29. Bede P, Elamin M, Byrne S, McLaughlin RL, Kenna K, et al. (2013) Basal ganglia involvement in amyotrophic lateral sclerosis. Neurology 81(24): 2107-2115.

30. Yoshor D, Klugh A 3rd, Appel SH, Haverkamp LJ (2005) Incidence and characteristics of spinal decompression surgery after the onset of symptoms of amyotrophic lateral sclerosis. Neurosurgery 57: 984989.

31. Yamada M, Furukawa Y, Hirohata M (2003) Amyotrophic lateral sclerosis: frequent complications by cervical spondylosis. J Orthop Sci 8(6): 878-881.

32. Hernández Hernández A (2013) Role of neurophysiological studies in the differential diagnosis of amyotrophic lateral sclerosis and cervical spondylotic myelopathy. Acta Neurol Colomb 29(1): 53-59. 